Journal homepage : http://www.interscience.org.uk

DOI:10.31142/ijahm/v8i3.06

Impact Factor: 4.415

\title{
Garbhini And Garbhiniparicharya-A Review
}

\author{
${ }^{1}$ Vyas Deepak M., ${ }^{2}$ Umarkar Suwarna V., ${ }^{3}$ Thakare Prabhakar B., ${ }^{4}$ Thakare Mangala P. \\ ${ }^{1}$ Associate Professor in Dept. of Kriya Sharir, Jupiter Ayurved Medical College, Nagpur \\ ${ }^{2}$ Assistant Professor in Dept. of Kriya Sharir, Govt. Ayurved College, Nagpur, \\ ${ }^{3}$ Associate Professor, R.A. Pottdar Ayurved College, Mumbai, \\ 4Associate Professor, Govt. Ayurved College, Nagpur \\ Corresponding Author: Dr. Deepak M Vyas \\ 201 Arihant Apartment, Behind Akash Mall,Ayachit Mandir Road, Mahal, Nagpur.440032.
}

\begin{abstract}
:-
God has empowered each living being to produce itself and thus to perpetuate its kind of race. He has given this magnanimous gift only to the women. The woman is considered as one of the most essential factors of the continuity of the human race. During Garbhavastha, She experiences lots of anatomical as well as physiological changes at the level of Dosha, Dhatu and Mala. These changes are nothing but maternal adaptation to the increasing demand of the growing fetus. The Growth and development of fetus requires more nutrition from mother. This cause increased the workload on the maternal Dhatus so she needs extra nutrition during Garbhavastha. Ayurveda has suggested a very good protocol i.e. Masanumasik Garbhini Paricharya. The aim of this paper to is to study concept of Garbhini and Garbhini Paricharya from Ayurvedic literature
\end{abstract}

KEY WORDS:- Garbhini, Garbhini Paricharya, Garbhavasta, Aahar

INTRODUCTION:-“The woman is the origin of the Progeny". Garbhavastha is one of the most important events in the life of every woman .Ayurveda has suggested a very good protocol for that. It has given a detailed description of Aahara (life style), Vihar and Vichar (thought process) to be followed during Garbhavastha. These factors directly affect Garbhini as well as her Garbha. Ayurveda compares human conception with germination, sprouting of a seed and its transformation into sampling. The Mature age of women including physical and psychological health is an essential factor for good progeny during pregnancy. There are progressive anatomical and physiological changes not only confined to the genital organs but also to all systems of the body. This is principle phenomenon of maternal adaptation to the increasing demands of the growing fetus. The aim of this paper to is to study concept of Garbhini and Garbhini Paricharya from Ayurvedic literature.

During first Month of Garbhavasta, the signs and symptoms appear immediately after conception are named as 'Sadyo Grihita Garbha Lakshanas'. The various Lakshanas of Sadyo Grihita Garbha are Nishthivika, Gauravam, Angasada, Tandra, Praharsha, Hridayavyatha, Tripti, Srama, Glani, Pipasa, Sakthi Sadanam, Yoni sphuranam, Hrullasa, Paseka Hrudaya spandanam. (1) (2) (3) During Sadyo Grihita Garbhavasta, the activity of Rasa Dhatu becomes more prominent. Hence, Kapha Dosha activity also increases. So, the above symptoms appear. According to Charaka and Chakrapani in second and third Month, that Dauhrida's Abhivyakti, Grihita (Vyatka) Garbha Lakshanas start. The signs and symptoms of Vyakta Garbha Lakshanas are Artavadarshnam, Aasya samsravanam, Annanabhilasha, Chardi, Aamlakamta, Guro gatrta, Chakshushorglani, Stanayoh, Stanyapravritti, Mandala Krishnata, Roma Rajyudgamah, yonyaschatalatvam, Subhagandh, Udvejanam, Sadanam, Kukshi Gauravam, Swara Kshamata , Nidradhikyata, Jrimbha, Moorcha, Kshamata ,Stana Peenata ,Vidaha . (4) (5) (6) (7)

In fourth Month, Garbhini attains Guru Gatrata due to Sthirata of Garbha. According to Kashyapa (8)'in fifth Month Garbhini becomes emaciated due to lack of nourishment of maternal Dhatu as the Rasa is driven to 


\section{Vyas Deepak M. ${ }^{1 *}$, International Journal of Ayurvedic \& Herbal Medicine 8(3) May.-June. 2018 (3241-3244)}

nourish more and more the flesh and Shonit of the fetus. (9) Mother attains Karsyata due to the gain of Mamsa and Shonit by fetus Here Karsya does not denote weight loss but in contrary, the loss of Mamsa and Shonita Bhavas in the mother. Chakrapani also explains that after Garbha Poshana, Ksheen Aahar Rasa is not so nutritive for Poshana of mothers Dhatu. In sixth Month, as the fetus attains the Upachaya of Bala and Varna, there is loss of Bala and Varna in the mother. (10) Kashyapa, in this month, adds Oja Vriddhi to the fetus. Hence, mother undergoes Shrama. Bala is nothing but Shakti. Oja is Sarva Dhatu Sara. While, these two are getting transferred to fetus, naturally mother feels tiredness. In seventh Month the fetus gains all the Bhava and attains maturity and gain strength. The Mother loses all these Bhava, she feels exhausted or has relatively more losses of flesh and Shonit, thereby she becomes weak. (11)

In eight month the transfer of Oja from mother to fetus occurs in the entire month. Vagbhat has specified that if under such condition of Oja Asthirata, birth of the baby takes place and if the Oja enters the fetus, the mother's life is at risk. Arunadutta has clarified the 'Samsaya' by stating that the mother may live or may not live. If diet and health of Garbhini is normal she gains considerable weight from fourth to seventh month, hence the question of emaciation does not rise. Deposition of pigments of the body might have been reflected as loss of complexion. The working capacity decrease due to increased intra abdominal pressure and reduction in hemoglobin concentration due to haemodilution might have been referred as loss of strength and blood respectively.

Sushruta and Bhavamishra have mentioned Dauhrudayavasta period in fourth month of Garbhavasta. Others Aacharya have not mentioned this period separately but have referred it in the description of fetal development. The difference in period by various authors is probably due to relative sensitivity of the women for feeling of quickening. Charaka opines that when Indriyas of the fetus become conspicuous the Mana gets association of Vedana or feelings of happiness and sorrow during same period due to this the fetus starts quivering and expresses the desires based on the experiences of its previous life. In fourth month of Garbhavastha the fetal heart becomes active and there is more requirement of Dhatu for the growth and development of fetus, it can be express by mothers craving for specific Aahara vihar. There is increase workload of Dhatu in this month. So body tries to fulfil this stage of diminutation and it is well known establish fact that the status of other Dhatu is depend on Rakta so it is very important to fulfil the Raktalpata. So in this stage there is craving for Amla Dravya like pickles, Lemmon, Turmerid. Actually there is no craving for particular food but it is craving for something in that food i.e. (craving for eating mud is suggestive of deficiency of iron and calcium). Charaka says that as desires of the fetus are expressed through the mother hence dauhrudya should always be fulfilled because the negligence or non fulfillment can cause abnormality or even death of the fetus. ${ }^{(12)}$

\section{Masanumasik Garbhini Paricharya:-}

Garbhavasta is a state in which all physiological functions are stimulated in order to meet demand of growing fetus. The growth and development of fetus need more nutrition from mother. This cause extra workload on maternal Dhatus so she needs extra nutrition during Garbhavasta. ${ }^{(13)}$ Charaka says that Garbhini is fit for the use of bruhana (anabolic) therapy. Vagbhata suggested external (for preparing water for bathing or irrigation etc.) and internal (powder, cold percolation, decoction etc.) use of Jiwaniya group of drugs. Affectionate and good behavior of husband and servants helps in maintenance of pregnancy. Milk provides nourishment and stability to the fetus; meat helps in achievement of pregnancy, provides nourishment to the fetus, suppresses Vata of pregnant woman, meat soup is superb medicine for her. Yogaratnakara has enlisted following food stuffs beneficial for pregnant woman i.e. salt and Swastika rice, Mudga (green gram), wheat, flour of parched rice, butter, Ghruta, milk , Rasala (curd mixed with sugar and condiments), honey, sugar, jack-fruit, banana, fruit of Amalaki, Drams, sour and sweat substances; anointment with cooling agents, musk, sandal and camphor; wearing of garlands; moonlight bath, massage, soft bed, cool air, anabolic or gratifying edibles, embracing beloved and other pleasing mode of life along with desired food.

The month wise Paricharya helps in proper development of fetus and gives health to mother. By following the timely regimen described gives benefits to, the mother's and her body parts like abdomen, flanks, back and genital organs become Mrudu and Anulomana of Vayu occurs. The natural urges are expelled out easily, through their respective passages. The skin and nails become smooth and Garbhini attains high degree of Bala, Varna and Oja. All these factors contribute in the full development and delivery of a child with all 


\section{Vyas Deepak M..$^{1 *}$, International Journal of Ayurvedic \& Herbal Medicine 8(3) May.-June. 2018 (3241-3244)}

qualities and health. Contrary to this, if a Garbhini does not follow the above said Paricharya that may result in many problems regarding health of both mother and fetus and also result in such complications which may need immediate attention. Our ancient Acharya know well that not only the food and environment play a vital role in the development of fetus but also maternal psychic impressions have their impact on a growing fetus. Hence, they have given equal importance to all factors.

Ayurveda has suggested a wholesome diet during the period of Garbhavasta. This result in fetal growth, maternal health and post delivery lactation. In first month Garbha is in Kalal form and it get nutrition by Upsnehana. So Garbhini should take proper diet to make balance of Rasa and Rakta Dhatu. In second month Garbha start to take compact form with limb and head. Madhur Rasa Dravyas provide nutrition to Garbha. In third month different body part start to differentiated, heart beat initiate with sensory and motor reaction. In this period Garbha express its desire through mother's craving. Fulfilling this craving is helpful for proper growth. If one neglects Vata get vitiated and deform Garbha. ${ }^{(14)}$ During the first three months fetal growth organ are only in stage of formation and maternal Rasa and Rakta dhatu are used for nourishing the uterine bed. Hence more Jaleeya [liquid] substances are advocated.

In fourth and fifth month Mamsa Dhatu get nourishes in Garbha so Garbhini is advice to eat Jangal Mamsa. In sixth month fatty tissues of Garbha is formed. In Second trimester, the formation of fetal Dhatu starts and thus Ayurved suggested diet to boost this Dhatu formation which is the origin of the next chain of Dhatu, in the fifth month Rakta [blood] and Mamsa [muscle] are formed, in sixth month Med Dhatu is formed. In seven month most of Garbhini suffers from oedema of feet. This may be due to increase pressure on lower limb and water retention. To get relief from this Gokshur is advice as it is good diuretic .Around the seven month fetal growth is practically complete after which only refining work remains. In seven month Madhur Ksheer and Ghrit is advised which help in proper development of foetus. In last trimester Yavagu is advised and in nine month Astapana, Anuwasan Basti is advised for Sukhaprasav. Following Garbhini Paricharya the woman remains healthy and delivers the child possessing good health, energy, voice, compactness and much superior to other family members. ${ }^{(15)}$

\section{DISCUSSION -}

From above literature it is clear that milk and drugs of Madhura group have been advised for entire pregnancy period. Milk is a wholesome diet. It provides nutrition and stability to the fetus. The drugs of Madhura group are having anabolic property. Hence, the use of these drugs will help in maintenance of proper health of Garbhini and development of fetus. During $1^{\text {st }}$ trimester of pregnancy, most women have the complaints of nausea and vomiting. So, they cannot take proper diet. Use of cold, sweet, liquid diet and milk will prevent dehydration and supply required nourishment. From $4^{\text {th }}$ month onwards, muscular tissues of fetus grow sufficiently. According to the principle Mamsa Dhatu gets well nourished with its Svayoni Vardhana Dravyas i.e. Jangala Mamsa. Hence, Sushruta might advise the pregnant woman to take Jangala Mamsa. Kashyapa says that the meat soup which is taken by pregnant woman not only helps in achievement of pregnancy, but also provides nourishment to the fetus. It also suppresses Vata of pregnant woman. By the end of $2^{\text {nd }}$ trimester, most of the pregnant women suffer from such complications of water accumulation as edema over feet, use of Gokshura may prevent these disturbances, as it is a good diuretic. Yavagu, is advised by Charaka in $8^{\text {th }}$ month, the Garbhini remains free from diseases and delivers the child possessing best health, energy, complexion, voice, compactness of the body. Asthapana and Anuvasana Bastis help in Sodhana of Pureesha and Anulomana of Vayu which in turn leads to Sukha and Nirupadrava Prasava. So, the Garbhini who follows the above said Upakramas becomes Snigdha, gains strength and delivers normally and easily without any complication. Concept of Garbhiniparicharya is programmed with an objective of the birth of "Shreshtamapatyam". The benefits of these entire regimen, ensures the procurement of a "Supraja". (16)

\section{CONCLUSION:-}

In Ayurveda a scientific protocol is given for Garbhini Pricharya. It should be followed by Garbhini as it is necessary for formation of qualitative Rasa Dhatu which nourishes of Garbhini, her Garbha and helpful in production of milk. It is also helpful for proper functioning of Vayu (Apan Vayu) which is necessary for Sukhaprasav. 
Vyas Deepak M. ${ }^{1 *}$, International Journal of Ayurvedic \& Herbal Medicine 8(3) May.-June. 2018 (3241-3244) REFERENCES:-

1. Agnivesh, Charak, Drudbala. Charak Samhita. 2004th Ed. Tripathy B, Editor. Varanasi: Chaukhamba Surbharati; 2002.

2. Thakkar VJ, Rao P, Pandey A. Garbhavkranti. In Astangsamgraha,Sutrasharirnidan.: Kendriya Ayurved Aivm Siddha Anusandhan Parishad; 2006. P. 369.

3. Sushruta. Garbhavakranti. In Sharma P. Sushruta Samhita. Varanasi: Chaukhamba Orientalia; 2002. P. 352.

4. Sushrut. Garbhavkrantishariradhyaya. In Sharma P. Sushruta Samhita. Varanasi: Chaukhamba Orietaliya; 2002. P. 352.

5. Agnivesh, Charak, Drudbala. Mahtigarbhavkranti. In Tripathy B. Charak Samhita. Varanasi: Chaukhamca Surbharati Prakashan; 204. P. 883.

6. Thakar VJ, Rao P, Pandey A. Garbhavkranti. In Astangsamgraha. New Delhi: Kendriya Ayurved Avm Siddha Anusandhan Parishad; 2006. P. 441-442.

7. Paradkar Ss. Putrakamiya. In Kunte A, Navre K. Astanghridayam. Varanasi: Chaukhamba Sanskritbsanstan; 2011. P. 434-435.

8. A, Charak, Drudbala. Mahatigarbhavkranti. In Tripathy B. Charak Samhita. Varanasi: Chaukhamba Surbharagti Prakashan; 2004. P. 885.

9. Agnivesh, Charak, Drudbala. Mahatigarbhavkranti. In Tripathy B. Charak Samhita. Varanasi: Chaukhamba Surbharati; 2004. P. 885.

10. Agnivesh, Charak, Drudbala. Mahtigarbhavkranti. In Tripathy B. Charak Samhita. Varanasi: Chaukhamba Surbharti; 2004. P. 885.

11. Agnivesh, Charak, Drudbala. Mahtigarbhavkranti. In Tripathy B. Charak Samhita. Varanasi: Chaukhamba Surbharti; 2004. P. 886.

12. Umarkar SV. "The Physiological Study Of Raktalpata In Garbhini. 2009.

13. Umarkar S, Vyas D. Status Of sharir Dosha In Garbhini With Special Reference To Raktalpata-An Observational Study. International Ayurvedic Medical Journal. 2017 April.

14. Naga SLC. Concept Of Garbhini Paricharya. International Ayurvedic Medical Journal. 2013 Nov-Dec; $\mathrm{I}(6)$.

15. Anjumani Deka1 KK. Garbhini Paricharya And Its Clinical Importance. International Ayurvedic Medical Journal. 2017 May.

16. N VB. An Illustration Of The Garbhiniparicharya As Explained In. International Ayurvedic Medical Journal. 2017 June. 